\title{
Pentecostals and apartheid: Has the wheel turned around since 1994?
}

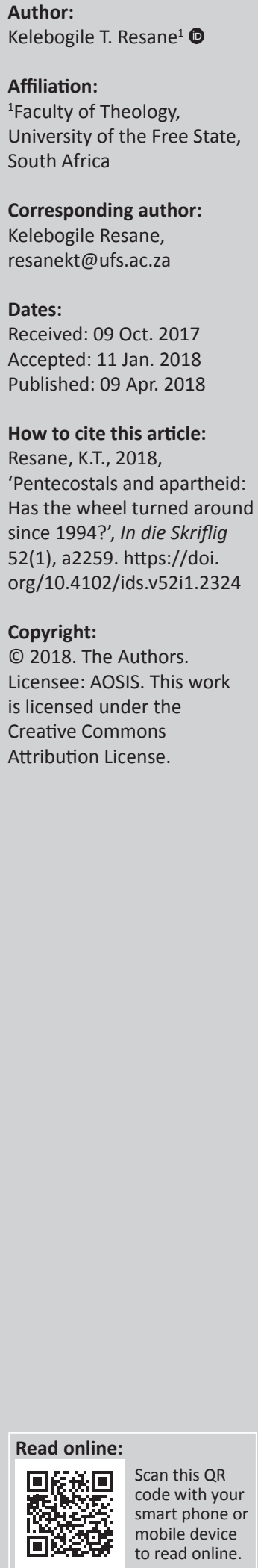

\begin{abstract}
The article gives a brief origin of the three classical Pentecostal denominations in South Africa, namely the Apostolic Faith Mission, the Full Gospel Church of God, and the Assemblies of God. The aim is to demonstrate the Pentecostals' docility in the socio-political space in South Africa due to their church governance, structures and polity designed along racial lines. The main question is: Has the wheel in these churches turned around since 1994 after the dawn of democracy in South Africa? The conclusion suggests that these churches should demonstrate intrinsic reformation by continuing with proclamation and participation activities to demonstrate their alignment with the new democratic dispensation. A brief summary is given of these churches' current activities in answer to the main question.
\end{abstract}

\section{Introduction}

This article focuses on the three classical Pentecostal denominations in South Africa, namely the Apostolic Faith Mission (AFM), the Assemblies of God (AOG) and the Full Gospel Church of God (FGC). The rationale behind selecting these three churches lies behind their historical and missiological metamorphosis through the apartheid era. The three denominations have a long history of South African socio-political complexities. The intention is not to give the history or the origin of these churches, but to trace their evolutionary processes and new shape since 1994. Each of these churches will be dealt with differently. The article concludes with an analysis of their evolutionary attempts towards the current geopolitical landscape.

\section{The three classical Pentecostal denominations} \section{The Apostolic Faith Mission}

This largest Pentecostal and missionary church emerged in South Africa in 1908, due to Zionist revival events run by John Graham Lake and Thomas Hezmalhalch (Clark 2005:144). Lake, who was 22 years younger than Hezmalhalch, became a prominent leader due to his powerful Pentecostal ministry of preaching and the divine healing. The healing ministry became the drawcard for the evangelist ministries held in the Central Tabernacle in Breë Street, Johannesburg. The venue became the origin of the modern AFM. Lake became so popular that the apartheid prime minister, Louis Botha, consulted him regularly for guidance on how to deal with issues concerning the black population (Chandomba 2007:27). From its inception, the African church or black Daughter Church was significantly blessed with charismatic leaders such as Elias Letwaba, Richard Ngidi, and lately Frank Chikane.

Historically, AFM cannot be sketched without a reference to Reverend P.L. le Roux who was a Dutch Reformed Minister and the first South African Afrikaans speaking leader of the AFM elected when Lake left South Africa. He was a missionary and under his influence several strong black leaders accompanied him to the AFM as the Zionist Branch of the AFM. Several of them left and eventually established some of the most important Zionist churches in Southern Africa. Due to Le Roux's influence, many black people as well as Afrikaans speaking people joined the AFM.

Although predominantly Afrikaans and African, the AFM acclimatised itself to the church racial division that was followed by the Dutch Reformed Church's polity. 'It seemed that when the NGK sneezed, the AFM caught a cold' (Resane 2017:169). Like many church formations in South Africa, the white leadership of AFM unashamedly identified with the socio-political developments of the time by holding the rest of the church in its sway. This inter alia was enhanced by the ensuing Afrikaner nationalism prevailing at the time and articulated since 1948. Anderson and Pillay (1997:234) capture this correctly that 'white members determined the constitution, and power was vested in an all-white executive council'. 
Compliance with the status quo found expression as a determined resistance to communism and Black Nationalism, and an emotional identification with Afrikaner nationalism during the later 1950s and 1960s of the 20th century. 'Championing justice was equated with rebellion, terrorism, communism or swart gevaar' (Resane 2016:3). Going otherwise was deemed as supporting 'swart gevaar' over white dominance. Church imperialism and patriarchism embraced and promoted separate development - another expression of apartheid. Clark (2005) states:

The now completely White-ruled AFM continued with a mission[s] practice of 'daughter churches', similar to that practiced by the Dutch Reformed churches. This eventually led to the establishment of $[a]$ four major groupings in the AFM: the White (parent) church, a large Black daughter church, a Colored (mixed race) daughter church, and an Indian daughter church. (pp. 144-145)

The spirit of the age, as pointed by Clark (2005:143), was that black people were pagans and objects of mission, and that white people were Christians bringing the civilising influence of Christianity to Africa. The spirit of dependency was exacerbated by this notion that white Christians are here to serve the black brothers. This paternalistic approach to missions was and still is regarded as prophetic role by many white South Africans. Leadership development for black leaders was offered at the inferior level. However, by the end of the 20th century, this was no longer the case, although it was a notion that remained the longest in the mentality of many Afrikaner Christian workers and politicians.

This remained a hallmark of AFM until the dawn of the new democratic era. The church was governed according to the apartheid state racial dictates. Chandomba (2007) confirms this:

Many problems have existed from the beginning of the movement, such as racial discrimination and divisions among the leadership of the church. The movement did not remain aloof from the political climate prevailing in South Africa, but was dragged into murky waters of politics. Especially in the Apostolic Faith Mission, the White leadership of the church were involved in politics, and the church split into the Black church and White church. (p. 71)

The wheel started to turn in 1996 when the four sections of the church gravitated towards unifying a composite church. In other words, the structure had to change to reflect the church in the new democratic dispensation. Polity is fundamental to the culture change of any organisation. To capture this historical evolvement, Clark (2005) notes:

In 1996, the four sections of the AFM united under a single constitution, with a democratically elected church government. It consists of over 30 regions, whose chairpersons make out the Executive Council (now known as the National Leadership Forum), together with the elected office-bearers of the church. In 2000 , the church voted for a new philosophy in church government, and now operates under a mixture of the old democratic constitution and the 'new apostolic paradigm' - a move from a Presbyterian system to an Episcopalian. (pp. 145-146)
The 2000 Constitution of AFM was elaborative and complex. Clark (2007) tries to unravel it:

The Executive Council was renamed the National Leadership Forum, and the Regional Councils were renamed Regional Leadership Forums. The senior local pastor of each assembly is now termed the assembly leader, whereas previously all accredited ministers and part-time ministers were simply referred to as workers. The largest representative body, called the Workers Council and which met annually, now became known as the General Business Meeting and convenes only tri-annually. Whereas it previously consisted of every accredited minister together with delegations from every local assembly board, it now consists of a significantly smaller group. Most of its powers have been removed and given to the National Leadership Forum, while the day-to-day running of the church as a denomination is the task of the four National Office Bearers (President, VicePresident, General Secretary and General Treasurer) who enjoy significant executive authority. (p. 42)

In a nutshell, the Composite Division of the church unified officially and structurally with the white church in 1996 with multiracial structures as per votes. The question that remains is: Has the wheel turned around? Is AFM a non-racial denomination in South Africa? Since the Constitution of 2000 , is there evidence that the church has reformed?

\section{The Assemblies of God}

The first missionary was a Canadian, Charles Chawner, who arrived in 1908 and planted the seed. Coming from a small Pentecostal fellowship in Toronto, he embarked on a mission field to South Africa without any financial support. He arrived in South Africa with his wife to do itinerant ministry - operating from a small mission station in Zululand. The other missionary couple that arrived in 1908 was Henry and Anna Turney from an American Baptist background. They also had a Pentecostal experience and felt led to the mission field in South Africa. Together with Hannah James from England, they became a team ministering the black people in the Pretoria area. In 1911 this team of three moved to Doornkop near Middelburg in the Eastern Transvaal to establish a very successful mission station. In 1914 when the AOG was constituted in Hot Springs, Arkansas, the team of three applied for membership and this was accepted in 1917. Immediately 'Turney registered the name Assemblies of God with the Department of the Interior in Pretoria (Watt 1992:21). This development qualifies the AOG as a historically missionary church. This 'group' or 'conglomerate' co-existence under one umbrella limited a hierarchical organisation of the church. This fact is also attested by Clark (2005):

The notion of becoming AOG was simply to promote fellowship and to alleviate loneliness. As indigenous Black leadership developed in (or gravitated to) the AOG, the role of these expatriate missionaries became more peripheral, involving administration and education more than evangelization. Because 'missions' was such an assumption [at] the beginning, there does not seem to have been a time when it could be said that the AOG had an official missions policy in its constitution, or a local missions director or superintendent. (p. 151) 
The citing above leads to the conclusion that from its inception, and to a certain extent in its current form, AOG was an umbrella body under which different groups operated autonomously. These groups disintegrated, reformed and ultimately reformulated into the current tri-cameral or tripod structure based on racial lines as per the dictates of the apartheid government's ideology of separate development. Anderson (2000) has this to say:

In a racially divided society this structure was construed as lending support to such division, and this was the main criticism of the AOG by its younger black leaders at the time. One told me that he and many other AOG leaders were 'definitely against' the group system. One of the main reasons was not that the AOG actually had an apartheid system but that this was what it appeared to be to outsiders. It is thought that the divided structure would remain until new and more enlightened leaders arose to change it. (p. 105)

The AOG is a multiracial church, with black people as a majority, due to the influential and inspirational ministry of Nicholas Bhengu who joined AOG in 1937. It is also recorded that, since the 1930s, ' $t$ this was a mainly Black church with only a small number of White members' (Chandomba 2007; Watt 1992).

Currently, the AOG is structured under one General Executive which had always been multiracial. Each of the three groups' polity differed from the other. The Movement (formerly Back to God) operates and governs itself under the Executive Committee. The Association (mixed race people and Indian people) is led by the Apostolic Team, while the Group (formerly white people) are under the National Leadership Team. The three groups differ from each other, although they operate under one General Executive and hold a biennial General Conference. The division along colour or racial lines is still significant with racism subliminally operative. However, of the three classical Pentecostal churches under discussion, the AOG boasts the track record of never barring any person from fellowship due to race or colour as per their constitutional dictates. This is also captured by Clark (2005:149): 'Even the non-racial AOG developed on the lines of White assemblies and Black assemblies, for all that they were not forced to do so by their constitution.'

The bottom line remains that the non-segregated AOG, through its group system at grass-roots level, is more segregated than the officially segregated AFM where historically white people had no trouble working with and among their township brethren.

The other track record is that of the three churches, the AOG was never an Afrikaans church. It has always been an English indigenous South African Pentecostal church. One wonders: What if it was also an Afrikaans church? It can also be observed that most, if not all, group (white) churches are either multiracial or entirely black in membership.

\section{The Full Gospel Church of God}

Unlike AFM, the FGC has more English-speaking members, with a sizeable following of the Indian population group, due to the missionary zeal of J.R. Rowlands as from 1931. This church started in South Africa in 1910, when Bethel Pentecostal Mission of Newark, New Jersey sent a North American missionary, George Bowie, to this country. He was soon joined by other missionaries, notably Archibald Cooper from England who migrated to South Africa in 1902. The united mission of Bowie and Cooper split in 1916, but reunited in 1921 (Anderson \& Pillay 1997:235). This church did not thrive a great deal in the black communities until later. The white people controlled the legislative body and the constitution extensively.

FGC has some historical landmarks of black people contending for one united church with no colour bars. 'The first open agitation for unity within the FGC began in 1975, initiated by the three black constituencies' (Anderson \& Pillay 1997:235). This led to the formation of the non-racial Ordained Ministers Council (OMC) in 1986. Right up to 1995, contests and contentions ensued for racial unity within the church. From their website, one learns that negotiations for change were in progress for some 16 years and those communities that decided to unite became one integrated association within the FGC. In March 1990 the United Assemblies of the FGC was constituted, consisting of the majority of the black community, mixed race community and Indian community, and a small group from the white community. The church now had two groups instead of four. These were Irene Assemblies and the United Assemblies. More than 7 years later, in October 1997, the whole FGC in Southern Africa united to become one structural organisation. This made the FGC a non-racial and structurally integrated church.

\section{The Pentecostals in the socio- political landscape}

White Pentecostals were, except for a few voices, generally passive towards racial segregation. The policies of the apartheid state protected their comfort zones and their supremacist egos of preserving their European-ness and ethnic identity. Walshe (1997), in reference to Evangelicals and Pentecostals, captures this assertion that:

Although prophetic dissidents emerged from within each cluster of churches, neither offered a critique of the established political order, and both condemned liberation theology. Only a minority of Evangelicals and Pentecostals criticized their faiths' other worldly theologies, whose effect was to abet the status quo. (p. 389)

The two sacraments of the New Testaments are designed for expressing or demonstrating the communion of believers with Christ. In South Africa the two sacraments were used to divide the body which was intended to be united. Since 1857, racial segregation in the Dutch Reformed Church started on the Holy Communion Table. For Pentecostals, through AFM, 
racial segregation was initiated through baptism. Anderson (2000) gives a panoramic view from as far back as 1908:

A minute dated 17 September 1908, apparently at Lake's instigation, spoke of 'the necessity of getting adequate accommodation for the holding of services in Doornfontein especially for the coloured people'. Less than two months later, they decided that 'the baptism of Natives shall in future take place after the baptism of the white people'. At the executive meeting in February 1909 it was decided that the superintendent over the 'Native work' must be white. The minutes of July 1909 read: 'In future, the baptism of Whites, Coloured and Natives shall be separate'. (p. 85)

The sacraments were used to divide the people of God. This created isolation, secession, and polarisation - all leading to racially divided Christian communions. Parochialism created racial enclaves - not to mention disengagement from sociopolitical issues that could improve quality of life. The racially divided church cannot enact the united witness.

Nicholas Bhengu of AOG rarely made socio-political pronouncements (Anderson 2000:91). He was convinced that the gospel is the liberator of black people from any political or economic oppression. This confirmed his critics that he was using the gospel as an opium - a critical diversion taken by Marx's version about religion. 'He did not challenge the status quo, believing that political activity was futile, and forbidding his members to affiliate politically' (Anderson \& Pillay 1997:239). Dubb (1976) enlightens us that:

Bhengu did, in fact, hold out a promise of national redemption - but through non-violence, good relations with Whites, obedience to the laws of the land and, above all, through faith in God rather than in political action. (p. 27)

However, it can be noted that he was a reconciler and a peacemaker with friendships across the dividing walls of hostilities. He personally related to traditional leaders, kings, homeland leaders and politicians in and out of a structured civil government. Lephoko (2005) points this out:

Bhengu was a brave man, a man who would not bow to pressure from any quarter, be it from the Liberation movements or a King, Homeland or Traditional leaders or government. He invited whosoever he wished to his conventions in East London, Bloemfontein, and Thaba Nchu including representatives of the South African Government. For example he did not hide his friendship with Dr Piet Koornhof, the then Minister of Bantu Affairs in PW Botha's Cabinet. (p. 71)

These relationships were on a personal level and not intended to prophetically point out the need to liberate the masses from the evil clutches of apartheid. This is one mark that the Pentecostal leaders or leaders of the major Pentecostal churches will carry in their seared consciences for generations to come. They hypothetically did not see anything wrong with socio-political disengagement. Very few of them took the advantage of appearing before the Truth and Reconciliation Commission (TRC). For instance in 1996, a white leader of the newly united AFM, Isak Burger, apologised publicly at a live televised meeting for the attitude of white Pentecostals toward their black brethren. The occasion was graced by the presence of President Thabo Mbeki. The AFM also made a representation at the TRC where the white church showed its remorse over its participation in evil practices of apartheid. On the other hand, ironically, AOG did not appear before the TRC or make a similar confession, citing that this was never the case in their movement. Although they refused to identify with the liberation theologians and the ecumenical movement (believing that church and politics do not mix), they claimed that they did not practise racial discrimination in their church government (Clark 2005:155). Pentecostalism's eschatology with its apocalyptic trends that determined its hermeneutics and theology justifies its escapism mentality as Kumalo (2014) explains:

Pentecostal theology is based on a belief in the second coming of Jesus that will end the suffering experienced in this world. This otherworldly theology emphasizes escaping this current sinful and hurtful world, to the better one, Heaven eZulwini, which is referred to as a 'home', ikhaya, where Jesus is. This emphasis tends to disconnect its members from social engagement and a sense of belonging to the broader community. (p. 224)

However, it should be noted that the Pentecostals were not completely absent from political engagement. In many parts of the world Pentecostals occupied positions of power in politics, businesses and professional vocations. A new wave of Pentecostals is serving in a broader spectrum of human habitat. In Latin America Feliciano (2005) stated: 'Scholars of Pentecostalism and politics fail to explain the reasons for a Pentecostal explosion into formal politics in 1986.' Even where politics were disrespectful of human rights and dignity such as apartheid South Africa, some Pentecostals were in positions of power. From the AFM in South Africa, one can trace this historical involvement. For instance as Anderson (2005a) alludes:

A vice-president of the church until 1969, Gerrie Wessels, became a National Party senator in 1955, and the wife of a government minister and later State President, Jim Fouché, was a member of the church. (p. 8)

Beyond the borders of South Africa one can also cite the former heads of state of Zambia (Frederick Chiluba), and recently, Ghana (John Dramani Mahama). There are hundreds of political leaders who are Pentecostal or Charismatic throughout the world.

The 1980s was a decade of political explosion in South Africa. The Botha regime hurled the explosive bomb of injustice ad summum [to the highest point]. Christianity was rattled to the core, especially African Christianity which was at the receiving end of the fiery spews of repeated states of emergency, detentions without trials, deaths in detention in the hands of the security forces, bombings and arsonist acts on Khotso and Khanya Houses, preachers of the gospel detained under suspicions of communism and terrorism acts, military hits on the neighbouring states, and so on. 
Like many Christian leaders, some Pentecostals such as Frank Chikane and others, took their stance and stood for justice and righteousness. Their churches and their faith were severely affected by the government's acts of murder, destabilisation and human eliminations. Anderson and Pillay (1997) comment on this:

In the 1980s the struggle for unity in the Pentecostal churches, encouraged more outspokenness against apartheid. For example, Pentecostals comprised at least half of the signatories of 'The Evangelical Witness', drawn up by the Concerned Evangelicals in 1986 as a reaction to the perceived political conservatism of Evangelicalism. In 1988 a group of Pentecostals from Natal (mainly Indian) drew up 'The Relevant Pentecostal Witness', a more specifically Pentecostal statement against apartheid that stressed the non-racial origins of the Pentecostal movement and a theology of the Spirit motivating a preference for the poor and oppressed. (pp. 239-240)

This shows that the state brutality of the 1980s was a wakeup call for Pentecostals. They witnessed their members being tortured, detained and banished. They were left with no option but to engage. It can be pointed out that the Pentecostals of all races started to be involved and engaged in the resultant ecumenical initiatives such as the South African Council of Churches, Evangelical Fellowship of South Africa, Concerned Evangelicals and many others in the localities.

\section{Has the wheel turned since 1994?}

As in all Christian formations in South Africa, structural racism was found to be heretic and dehumanising. Prophetic docility could no longer be tolerated, 'for Indian or [B]lack churches not to address the injustices that affect them daily is tantamount to accepting their disenfranchised lot without complaint' (Pillay 1994:161). This scenario took some dramatic turns in order to synergise with correct theological and democratic ideals of the new South Africa.

It is unquestionable that Pentecostals in South Africa are now prophetically engaged. They are characteristically marked by their briller par son absence from socio-political activities. Racial segregation was entrenched and engrossed within their polities, liturgies and sacraments, but this has taken a new turn of embracing and discarding many, if not all, forms of social exclusion. They reject or criticise the polity - the way they governed themselves - which was an ultimatum of their theological biases based on the secular ideals of the apartheid regime. Anderson and Pillay (1997:238) quote the article: 'The Church and Racism' in the AFM's magazine, The Comforter of September 1955, where 'C.P. du Plessis affirmed his belief in the mental, emotional and spiritual superiority of the white race, all based on the Scriptures'. This was and still is exacerbated by the Pentecostal missiological outlook not merely focussed upon the historical present but the 'eschatological consummation of the world' (Kärkkäinen 2001:328). The focus is to bring all of humanity into the kingdom of God. Hence, the Pentecostal churches are currently characterised by a strong evangelistic thrust with proclivity towards socio-political engagement.
For decades, even before 1994, the Pentecostals in South Africa have realised that the divided ecclesia is not authentic to bring the good news of salvation to the marginalised and poverty-stricken masses. It is justifiable that the three classical Pentecostal denominations examine the way in which they were structured, because, as Pillay (1994:161) notes, 'it is wrong to suppose also that their church structures would remain the same and escape reformulation'. Structural change enhances cultural change. The efforts of unity in the AFM and FGC are visible, and as the united communions, they participate in community-based projects that address human needs.

Some South African Pentecostal voices are still reverberating within the political structures with the intention of bringing justice and righteousness to the fore. They play their roles in their spaces to let justice roll on. The Centre for Development and Enterprise (Schlemmer 2008:72) conducted a survey among the Pentecostals in 2007 and 2008 and encountered 25 politicians or other social activists who are Pentecostal or Charismatic Christians, most of them black people. This report continues to inform us:

Although Pentecostals were generally politically inactive before the first democratic elections in April 1994, since then a few prominent leaders have aligned themselves with the spirit and goals of liberation from apartheid. (Schlemmer 2008:76)

Since 1994 there are signs of black Pentecostal participation in the public sphere. An example is a Pentecostal pastor, Kenneth Meshoe, leader of the African Christian Democratic Party (ACDP), who was elected with one other representative to the national parliament. Pentecostals dominate the ACDP, but it remains to be seen whether this party will play a more significant role in future South African politics. Another example is the former President of the 'Bantustan' Bophuthatswana, Lucas Mangope, who is a member of the AOG. He led the smaller United Christian Democratic Party which was also in parliament since 1999, but lost all seats in the recent elections of 2014. These two parties, although a minority, demonstrate that Pentecostals can engage politically to foster social justice in socio-political landscape. There may be a further indication of the increasing participation of Pentecostals in public life, albeit on the more conservative side of the political spectrum.

South African church history demonstrates that the Pentecostals never built schools, hospitals or community projects to uplift the quality of people's lives. The projects existed mostly for white beneficiaries, as these social welfare initiatives could not be open to serve all racial groups due to the policy of the land at the time. Post-1994, the wheel turned around. Despite the bursaries it had been offering for education during the apartheid era, AOG can now boast of numerous projects such as the high school offering basic education in Henley-on-Klip, south of Johannesburg; a number of schools, especially in the Western Cape among the poor communities; Sekusile Adult Basic Education in Durban; aggressive AIDS programme spread throughout 
the country; health centres for the historically marginalised communities; early childhood programmes capacitating teachers for community early learning centres, and so on. These are championed and run by different sections of the church under one umbrella.

According to their website (Our history - Full Gospel Church S.A n.d.) the Full Gospel Church (FGG) has two old age homes and several crèches operating on a local assembly basis. In addition, various 'feeding schemes' are operated by local churches and more are in the 'pipeline'. There is one school that operates the 'Accelerated Education Programme'.

The AFM is a rich reservoir of projects that addresses the needs of South African communities. Their website (Apostolic Faith Mission n.d.) gives an opportunity for voluntary participation in their projects. These projects include poverty alleviation through job creation, skills development, education as well as efforts to promote reconciliation in South Africa, HIV and AIDS programmes and crime prevention initiatives. There are numerous initiatives in communities that are intended for connection and increment of the church's impact on South African society. The AFM has become a non-racial missional church with a global outlook rather than the historical white people going to black people as a missiological obligation:

The new unity constitution of the AFM (adopted in 1996) does not allow for any racial distinctions to be made in terms of membership, office or ministry in the church. In effect, this deprives the church of any notion of 'missions' activity within its own ranks, since until unity 'missions' was always understood as 'White going to Black' and as 'White giving to Black'. The Missions Department of the AFM has for some time been known as the Department of World Missions and Evangelisation, with the proclamation of the gospel in South Africa being understood as 'evangelization', and to non-Christians (e.g., Muslims) outside of South Africa as 'world missions'. (Clark 2005:150)

These Pentecostal initiatives demonstrate that transformation and participation in wider society takes many forms:

including relief activities, the saving of souls, the establishing of facilities for social welfare, and the shaping of public opinion through mass media. (Anderson 2017:38)

The social activities of the Pentecostal churches are extensive and obvious to any casual observer. Their ministry among the poor, the opportunities given to women leaders, and the educational and training activities demonstrate the potential within Pentecostalism to be a force for social transformation.

\section{Conclusion: Proclamation and participation Proclamation}

These three classical Pentecostal denominations 'have been victims of their own prejudices and captives of the apartheid system that ruled South Africa until 1994' (Anderson 2000:85). The bottom line according to Clifton and Ormerod (2007), is that South African Pentecostals as part of the global movement: [i]n recent years ... started to appreciate that the proclamation of a 'full gospel' includes not only evangelism (as traditionally understood) but also a social dimension, there has been an increasing desire for the movement as a whole, and for individual members in their own right, to achieve political influence. (p. 229)

The historical bearing of non-involvement where conversion was deemed as the solution to human misery, leaves Pentecostals with scarred integrity. However, in this new dispensation, they are called upon to unanimously and in unity proclaim the non-partisan gospel. The Pentecostal

church's political responsibility begins in its proclamation of Jesus and the Kingdom of God, and in the teaching of the religious values of faith, hope and love that stimulate personal transformation and personal values, and that result in the reframing of personal priorities, an orientation to the beautiful, the good and the true and, therein, to the mission of defeating evil and seeking justice and liberty. Exactly how these values will translate to the political and economic realms is not direct or obvious and, therefore, political and economic policies should not be given the status of a divine imprimatur. (Clifton \& Ormerod 2007:239)

The proclamation activities synthesised or enthused by the Holy Spirit should address the human misery brought about by the decadent political regimes and factions at hand. Kerygma is theology in action. Proclamation activities without incarnational exertion nullify the validity of theology in context. The authentic Pentecostal message should lead to the total liberation of humanity from the clutches of evil socio-cultural structures. If the message is merely for conversion, it will be irrelevant to the human needs in current South Africa.

Proclamation activities come through ministerial training and formation in and out of the classroom. Pentecostal preachers are to be shaped in such a way that Pentecostalism does not lose its distinctiveness. McKinney (2000) pleads:

Anointed Pentecostal teaching is required in the classroom, and while the Spirit and the word combat and diffuse any efforts to thwart the effectiveness of the teaching/learning experience, there are times when teacher and students must take the authority given them by Christ and rout the enemy forcibly. This must be modelled by instructors and experienced by students in educational institutions if it is to be practiced in their ministries. (pp. 256-257)

Pentecostals must continue their vigorous hermeneutics in their diversities and kerygma, and be unashamed of their approach that Spirit-Word of Scripture should take priority over church and creeds. One of the hallmarks of Pentecostalism is that the Spirit is over the church. The Spirit was before Scripture. Land (2010:100) notes: 'So, the order of authority was Spirit, Scripture, church. Without the Spirit there would have been no Word, incarnate or written; without the Word, no church.' A similar notion is asserted by Archer (2009) in his monograph. After all, the authenticity of the church is established by placing her identity in the context of the apostolic witness and teaching articulated by Peter and the 
other disciples at the event of Pentecost (Thomas 2010:159). The first koinonia originated through kerygma. Without proclamation there is no church. Christian fellowship and witness is enhanced and solidified by the proclamation of the Scriptural truth. This kerygma must be both prophetic (identifying, naming and calling people to repentance) and didactic (exhorting, building and inspiring) to a community that is strong, proactive and assertive regarding social justice.

Because Pentecostal preaching appeals to the affections and to the anticipations of the possibility of an encounter with God, it inculcates a strong sense of awe and worship (Warrington 2008:202-203). This enhances a readiness to praise God or a determination to develop a Christian character and thus enthusing moral ethics. This is effected by the congregational participation and response in the sermon whereby people experience the biblical message 'rather than being characterized by a hermeneutics that spent its time exegeting a text in historical-critical manner' (Kärkkäinen 2002:5).

\section{Participation}

Participation refers to partnership or involvement: engagement in something for a common good, when koinonia demonstrates togetherness and unity for the common purpose. Resane (2017) asserts:

Christians are literarily partners with God. They are bonded together with God for a common purpose. Nothing is withheld in a true partnership. The resources of each one are shared with the other. (p. 3)

Joint consultation and collaboration of black people and white people in Pentecostal formations has been kick-started over three decades ago and should continue towards the desired outcomes and synergy of the biblical Pentecostal witness and fellowship. Hence, it was crucial for Pentecostals to deal with their structures and polity of post-1994 in order to become good stewards of resources at their disposal. Without this order and identity sorted out, witnessing would be difficult, if not impossible. 'Good governance and the prophetic witness of the church towards society are determined by the broader ecclesiological framework of what the church is' (Niemandt 2015:2). Resources, accumulated in and through one section of the church, should be evenly shared to build the kingdom that has been ruined for a century. South African white people, even in ecclesial formations, were far better resourced than their black counterparts. These resources, either in human, currency or intellectual property and capital, should be available for restoring human dignity as a way of healing our current polarised society. It is good to reflect on the picture painted by Anderson (2005b), in this instance:

The political responses of most White Pentecostals have been considerably influenced by the 'Religious Right' in the United States, but for Black Pentecostals, this influence is minimal. Prominent North American 'televangelists' Jimmy Swaggart, Pat Robertson and Kenneth Copeland visited the country in the 1980s and were among those who seemed to add their support to the beleaguered White government. The largest and wealthiest congregations in the nation are predominantly White, middle class, independent Charismatic churches in the Gauteng heartland, the best known being the Rhema Bible Church in Randburg near Johannesburg and the Hatfield Christian Church founded by Edmund Roebert in Pretoria and now led by Francois van Niekerk. Both churches are White-led and both proclaim a gospel of prosperity and health, especially Ray McCauley's Rhema with origins in the Rhema 'faith movement' of Kenneth Hagin in Tulsa, Oklahoma. These churches have assets worth millions, while for the vast majority of (Black) Pentecostals such wealth is an elusive dream. The White Pentecostals live in a totally different world from that of their Black counterparts, and this is not only true of newer 'Charismatic' churches but of 'classical' Pentecostal denominations too. With few exceptions, Black and White Pentecostals failed to overtly confront the political structures that oppressed them, and sometimes they even supported them. (p. 71)

The picture painted above has of course, in a recent past, taken some turns. It is a scenario predominantly found in the Neo-Pentecostal Movement that is not under this article's discussion. However, it is highlighted here, as it does not leave the classical Pentecostals unscathed. Some classical Pentecostal preachers had embraced the gospel of health and wealth, creating a middle class cohort of preachers, causing the imbalance of the access to the resources.

Sharing is partnership which implies participation. The parties involved cannot share without participation. Each partner must part with something for the sake of the other. 'Sharing implies the release of everything one has with one who is in partnership with' (Resane 2017:3). This is caring at its core. Levelling the imbalances of the past can be uncomfortable for the haves as opposed to the have-nots. The black Pentecostals and white Pentecostals are to become a platform on which the communities are empowered and the love of Christ is incarnated. Both camps must work in synergy and as a symbiosis to improve the quality of life.

The struggle still continues. Racism is relatively still an issue among the Pentecostals. Language and culture had been used as an excuse or a tool for separation of churches - concession that many of us do not buy into. There can be one church in different localities peculiar to their cultural or language idiosyncrasies. Church governance and structures have changed; yet, one particular race is still in control of the economies of the churches. Window dressing is an escapism mentality to impress the outside world that it is indeed 'we are one'. Time will tell when truth will prevail. However, gratitude and congratulations are due to the efforts made so far.

As in all church communes in South Africa post-1994, aluta continua!

\section{Acknowledgements}

\section{Competing interests}

The author declares that he has no financial or personal relationships which may have inappropriately influenced him in writing this article. 


\section{References}

Anderson, A., 2000, Zion and Pentecost: The spirituality and experience of Pentecostal and Zionist/Apostolic churches in South Africa, University of South Africa, Pretoria.

Anderson, A. 2005a. 'Pentecostals and apartheid in South Africa during ninety years 1908-1998', viewed 27 September 2017, from http://www.pctii.org/cyberj/ cyberj9/anderson.html

Anderson, A, 2005b, 'New African Initiated Pentecostalism and Charismatics in South Africa', Journal of Religion in Africa 35(1), 66-92, viewed 19 February 2018 from $\mathrm{http}: / /$ booksandjournals.brillonline.com/content/journals/10.1163/15700 http://books
66052995843

Anderson, A.H., 2017, 'Contextualization in Pentecostalism: A multicultura perspective', International Bulletin of Mission Research 4(1), 29-40. https://doi. perspective', International Bulletin
org/10.1177/2396939316674428

Anderson, A.H. \& Pillay, G.J., 1997, 'The segregated spirit: The Pentecostals', in R. Elphick \& R. Davenport (eds.), Christianity in South Africa: A political, social \& cultural history, pp. 227-241. James Currey, Oxford.

Apostolic Faith Mission, n.d., 'Find a project: AFM-AGS', viewed 11 September 2017 from http://afm-ags.org/projects-coming-soon

Archer, K.J., 2009, A Pentecostal hermeneutic: Spirit, scripture and community, CPT Press, Cleveland.

Chandomba, L., 2007, The history of Apostolic Faith Mission and other Pentecostal missions in South Africa, AuthorHouse, Milton Keynes.

Clark, M., 2007, 'Contemporary Pentecostal leadership: The Apostolic Faith Mission of South Africa - A case study', Asian Journal of Pentecostal Studies 10(1), 42-61.

Clark, M.S., 2005, 'Two contrasting models of missions in South Africa: The Apostolic Faith Mission and the assemblies of god', Asian Journal of Pentecostal Studies 8(1), 143-161.

Clifton, S. \& Ormerod, N., 2007, 'Pentecostals and politics', Asian Journal of Pentecostal Studies 10(2), 229-244.

Dubb, A.A., 1976, Community of the saved: An African revivalist church in the Eas Cape, Witwatersrand University Press, Johannesburg.

Feliciano, N.I., 2005, 'Politics, Pentecostals, and democratic consolidation in Brazil' viewed 27 September 2017, from http://people.carleton.edu/ amontero/ Ivette $\% 20$ Feliciano.pdf

Kärkkäinen, V.-M., 2001, 'Pentecostalism and the claim for apostolicity: Essay in ecumenical ecclesiology', in D. Parker (ed.), Evangelical review of theology, 25(4), p. 328, World Evangelical Fellowship, London.
Kärkkäinen, V.-M., 2002, Toward a pneumatological theology: Pentecostal and ecumenical perspectives on ecclesiology, soteriology, and theology of mission, ed. A. Yong, University Press of America, Lanham, MD.

Kumalo, R.S., 2014, 'Christianity and political engagement in post-apartheid South Africa', Political Theology 15(3), 220-230. https://doi.org/10.1179/1462317X1 $3 Z .00000000055$

Land, S.J., 2010, Pentecostal spirituality: A passion for the kingdom, CPT Press, Cleveland.

Lephoko, D.S.B., 2005, 'The mission of Nicholas B.H. Bhengu in a divided and polarised society: An analysis of the life, work and contribution to mission in Southern Africa of an important 20th century pioneer', MA (Theology) Dissertation Department of Science of Religion and Missiology, University of Pretoria, viewed 09 October 2017, from https://repository.up.ac.za/bitstream/handle/2263 /25014/dissertation.pdf?sequence $=1$

McKinney, E.L., 2000, 'Some spiritual aspects of Pentecostal education: A personal journey', Asian Journal of Pentecostal Studies 3(2), 253-279.

Niemandt, C.J.P., 2015, 'Together towards life and mission: A basis for good governance in church and society today', Verbum et Ecclesia 36(1), Art. \#1361, 1-10. https://doi.org/10.4102/ve.v36i1.1361

Our history - Full Gospel Church S.A., n.d. viewed 26 September 2017, from http:// fgcsa.co.za/about-us/our-history

Pillay, G.J., 1994, Religion at the limits: Pentecostalism among Indian South Africans, University of South Africa, Pretoria.

Resane, K.T., 2016, 'Ichabod - The glory has departed: The metaphor showing the church's prophetic failure in South Africa', Pharos Journal of Theology 97, 1-12, viewed 27 September 2017, from http//:www.pharosjot.com

Resane, K.T., 2017, Communion ecclesiology in a racially polarised South Africa SunMedia, Bloemfontein.

Schlemmer, L. 2008, Dormant capital: Pentecostalism in South Africa and its potential social and economic role, Johannesburg, Centre for Development and Enterprise.

Thomas, J.C., 2010, Toward a Pentecostal ecclesiology: The church and the fivefold gospel, CPT Press, Cleveland.

Walshe, P., 1997, 'Christianity and the anti-apartheid struggles: The prophetic voice within divided churches', in R. Elphick \& R. Davenport (eds.), Christianity in South Africa: A political, social \& cultural history, pp. 383-399, James Currey, Oxford.

Warrington, K., 2008, Pentecostal theology: A theology of encounter, Clark, London.

Watt, P., 1992, From Africa's soil: The story of the assemblies of god in Southern Africa, Struik Christian Books, Cape Town. 